\title{
Polskie ogrodnictwo w obliczu międzynarodowej konkurencji
}

Konkurencyjność definiuje się jako trwałą tj. długookresową zdolność do osiągania korzyści i utrzymania pozycji na rynku. Pozwala to na aktywną i skuteczną rywalizację zarówno na rynku krajowym, jak i międzynarodowym. Osiaganie określonych korzyści przez gospodarkę krajową lub jej sektor czy gałąź jest możliwe dzięki sile ekonomicznej znajdującej się w ich posiadaniu. Dotyczy to zwłaszcza kwestii dysponowania zasobami i ich jakościa, stopnia ich wykorzystania oraz właściwego zarządzania.

W skali kraju istotę konkurencyjności stanowią zdolność do zwiększania udziałów na rynkach eksportowych oraz utrzymanie relatywnie wysokiego tempa wzrostu popytu krajowego. O poziomie konkurencyjności przesądzaja przewagi danego kraju $\mathrm{w}$ dwóch obszarach - produkcji i zbytu. W sferze produkcji są to: niskie koszty pozyskiwania czynników produkcji, korzyści skali, stopień wykorzystania zdolności produkcyjnych, efektywność wykorzystania techniki i technologii, w sferze zbytu: dysponowanie oryginalnymi i wyróżniającymi się produktami, wysoka wartość użytkowa, dostępność oraz cenowa i pozacenowa przewaga.

Konkurencyjność sektora rolno-spożywczego w Polsce oceniana jest w ostatnich latach jako niska, mimo posiadania znacznego potencjału produkcyjnego zawartego w zasobach ziemi i w sile roboczej, a także dużego kapitału, szczególnie w sferze przetwórczej. Konkurencyjność jest obniżana głównie z uwagi na niską produktywność czynników produkcji, wynikającą z małej i rozproszonej skali produkcji, ze stosowania przestarzałych technologii oraz z niskiego stopnia integracji poziomej i pionowej większości gospodarstw. Rozproszona struktura sektora rolnego, mająca odzwierciedlenie głównie w małych i średnich gospodarstwach, decydująco wpływa na niezdolność do konkurowania na równych prawach z przetwórcami i sieciami dużych detalistów. Sytuacja ta jest wynikiem niskiej rentowności gospodarstw tego sektora, co przy wysokich kosztach transakcyjnych dodatkowo ogranicza inwestycje i tym samym rozwój gospodarki. Jako pozytywną cechę niskiej intensywności produkcji, będącej udziałem ogromnej części polskich gospodarstw, podaje się 
ich szanse na przestawienie się na produkcję ekologiczną. Również rozwój łańcucha dystrybucji żywności jest niewystarczający $\mathrm{z}$ uwagi na niedostatki w fizycznej strukturze rynkowej i we wsparciu instytucjonalnym oraz promocyjnym. W dalszym ciagu brak jest widocznych i skutecznych form kooperacji, koordynacji, informacji i komunikacji pomiędzy różnymi podmiotami działającymi zarówno w sferze produkcji, jak i przetwórstwa oraz na rynku żywnościowym.

Ocena konkurencyjności sektora ogrodniczego jest właściwie pochodną sytuacji w całym sektorze agrobiznesu. Wcześniej wyodrębniono 24 czynniki konkurencyjne, $\mathrm{z}$ których 11 uznawanych jest jako małe, 7 jako średnie, a tylko 6 odznacza się dużą konkurencyjnością. Podział ten traktowany jest jednak umownie, ponieważ konkurencyjność jest zagadnieniem wysoce złożonym i zaliczenie danego czynnika do określonego przedziału nie zawsze jest w pełni obiektywne. W niniejszym opracowaniu konkurencyjność sektora zostanie oceniona przez 2 najistotniejsze czynniki, jakimi są potencjał wytwórczy oraz zdolność do zwiększania udziałów na rynkach eksportowych.

Od kilku ostatnich dziesięcioleci sektor ogrodniczy zawsze miał znaczący udział w produkcji roślinnej. Na początku nowego stulecia wartość produkcji owoców i warzyw w produkcji roślinnej ogółem wynosiła $23 \%$, a wielkość produkcji towarowej ww. produktów ogrodniczych w stosunku do całej produkcji roślinnej to $40 \%$. Znaczący był również udział świeżych i przetworzonych owoców i warzyw w eksporcie rolno-spożywczym, który w ciagu ostatnich 5 lat wynosił średnio ok. 24\%. Należy podkreślić, że z wyjątkiem 3 lat na przełomie lat 90 . w ostatnim 20-leciu sektor ogrodniczy wyróżniał się dodatnim saldem handlu zagranicznego jako jedyny w całym kompleksie agrobiznesu, gdzie to saldo było niezmiennie ujemne aż do 2003 roku.

Eksport produktów ogrodniczych (tab. 1) składał się głównie z produktów przetworzonych takich jak mrożonki i koncentraty, które wspólnie stanowiły ok. 75\% wartości tego eksportu. W latach 1993-2003 spośród 4 grup towarowych największym średniorocznym ilościowym tempem wzrostu charakteryzował się eksport warzyw przetworzonych i był niewiele mniejszy niż w pozostałych trzech grupach łącznie. W ujęciu wartościowym największe średnioroczne tempo wzrostu miał eksport owoców przetworzonych oraz warzyw przetworzonych, natomiast świeże owoce i warzywa miały podobne tempo wzrostu eksportu. W 2003 roku najwyższą pozycje w ilościowym eksporcie wynoszącym 600 tys. ton miały owoce przetworzone. Dominującym produktem mrożonym od wielu lat jest niezmiennie truskawka, która stanowi średnio ok. $50 \%$ wszystkich eksportowanych mrożonek owocowych. Należy podkreślić, że coraz większe znaczenie zaczyna zdobywać mrożona wiśnia, której eksport w ostatnich latach osiagał poziom 50 tys. ton. Drugim - nie tylko pod 
względem ilościowym, ale również wartościowym - produktem z grupy owoców przetworzonych jest koncentrat jabłkowy, którego eksport w ostatnich latach przekroczył 200 tys. ton. Spośród produktów świeżych największy potencjał eksportowy osiągnęły jabłka (ok. 350 tys. ton) oraz cebula (ponad 150 tys. ton). Wzrósł też wyraźnie - do 60 tys. ton - eksport w grupie „warzywa pozostałe", co świadczy o tym, że na rynki zagraniczne oferujemy coraz więcej nowych produktów poza sześcioma produktami tradycyjnymi. W porównaniu z innymi krajami UE głównym atutem eksportowanych z Polski produktów ogrodniczych, decydującym o ich konkurencyjności, jest niska cena. Odnosi się to zwłaszcza do produktów świeżych, ale także do koncentratu jabłkowego.

Tabela 1

Srednioroczne tempo wzrostu eksportu w latach 1993-2003

\begin{tabular}{|l|c|c|c|c|}
\hline \multirow{2}{*}{ Asortyment } & \multicolumn{4}{|c|}{ Tempo wzrostu eksportu [\%] } \\
\cline { 2 - 5 } & ilość & wartość & ilość & wartość \\
\cline { 2 - 5 } & \multicolumn{3}{|c|}{ świeżych } & \multicolumn{1}{c|}{ przetworzonych } \\
\hline Owoce & 6,3 & 5,1 & 5,8 & 9 \\
\hline Warzywa & 5,7 & 5,3 & 13,9 & 8,7 \\
\hline
\end{tabular}

Źródło: opracowania własne na podstawie wydawnictw IERiGż.

Eksport świeżych i przetworzonych produktów ogrodniczych w ostatnich latach wynosił ok. 1,3 mln ton, a w 2003 roku nawet 1,7 mln ton, co stanowiło $21 \%$ w stosunku do produkcji ogółem owoców i warzyw, która osiagała w ostatnim okresie $8 \mathrm{mln}$ ton [Analizy Rynkowe...]. W ujęciu wartościowym w ostatnich latach eksport świeżych i przetworzonych owoców i warzyw stanowił ok. $40 \%$, np. w 2002 roku było to $2727,2 \mathrm{mln}$ zł wobec wartości produkcji globalnej tych produktów wynoszącej wówczas $6845 \mathrm{mln}$ zł, co stanowi $39,8 \%$. Liczby te świadczą nie tylko o znaczacej pozycji, jaką od lat osiagał sektor ogrodniczy w wymianie międzynarodowej, ale wskazują też na jego zdolność do dalszego wzrostu eksportu, a - co za tym idzie - również na szanse rozwoju tej gałęzi gospodarki w przyszłości.

Dynamiczny rozwój eksportu produktów ogrodniczych nie odbywał się kosztem rynku krajowego, czego dowodem w ostatnim 10-leciu mogą być zmiany, jakie zaszły w wielkości i strukturze spożycia warzyw i owoców w Polsce. Świadczy to o dużej zdolności dostosowywania się sfery produkcyjnej do rosnacych potrzeb w tym zakresie. Wyraźny trend wzrostowy w spożyciu owoców obserwuje się już od początku lat 90. Spożycie warzyw od kilkunastu lat kształtuje się na podobnym poziomie, jednak zachodzą zmiany w strukturze oraz równomierności spożycia w ciągu roku. Na uwagę zasługuje też fakt zmniejszającego się wyraźnie udziału samozaopatrzenia $\mathrm{w}$ spożyciu 
owoców i warzyw, choć nadal wynosi ono ok. $20 \%$ w przypadku owoców i ok. $30 \% \mathrm{w}$ przypadku warzyw. Udział wydatków na owoce i warzywa w wydatkach na żywność w gospodarstwach domowych znajduje się na 3. miejscu [Analizy Rynkowe...] po wydatkach na mięso i jego przetwory oraz na produkty zbożowe i wynosił $w$ ostatnich latach ok. 14\%. Po przeanalizowaniu wskaźników dochodowej elastyczności popytu można zauważyć wart podkreślenia fakt, że owoce oraz niektóre warzywa charakteryzują się dużą wrażliwością na przyrost dochodów, i to w większości grup społeczno-ekonomicznych.

Wielkość $\mathrm{i}$ istotny udział eksportu produktów ogrodniczych $\mathrm{w}$ wartości produkcji globalnej owoców i warzyw, a także poziom spożycia krajowego tych produktów wskazują że sektor ten posiada obecnie sporą potencjalną zdolność do zwiększenia swych udziałów na rynkach eksportowych przy utrzymaniu poziomu popytu krajowego. W tym momencie należy jednak postawić zasadnicze pytanie - na ile trwała jest to zdolność? Czy dotychczas zajmowana pozycja rynkowa oraz odnotowywane w tym sektorze tendencje rozwoju zdołają utrzymać się w długim okresie? Jaki jest jego potencjał wytwórczy, stopień jego wykorzystania, jakość i skuteczność zarządzania?

Oceny potencjału produkcyjnego dokonano na podstawie analizy danych ze spisów rolnych (1996 i 2002) oraz z wybiórczych badań przeprowadzonych w 2003 roku w gospodarstwach sadowniczych. W ciagu tego okresu nastapiły istotne zmiany w wielkości upraw oraz w strukturze obszarowej gospodarstw ogrodniczych. Produkcja sadownicza wzrosła o 30\% przy wzroście powierzchni sadów o $11 \%$, natomiast zbiory warzyw zwiększyły się o $8 \%$ przy zwiększeniu powierzchni upraw warzywnych o 10\%. W okresie 6 lat, (1996-2002) zmniejszyła się prawie o 60 tys. liczba gospodarstw sadowniczych - były to głównie gospodarstwa najmniejsze o powierzchni do 1 ha. Zwiększyła się natomiast liczba gospodarstw mieszczących się we wszystkich większych przedziałach obszarowych. W 2002 roku gospodarstw, które można uznawać za towarowe (tj. większych niż $5 \mathrm{ha}$ ) było 9686 , co stanowiło 3,55\% wszystkich gospodarstw sadowniczych w kraju. Znacząca zmiana miała miejsce w liczbie gospodarstw warzywniczych, których ubyło ponad 1 milion. W dalszym ciagu sa to jednak gospodarstwa bardzo małe - ponad $60 \% \mathrm{z}$ nich zajmuje powierzchnię poniżej 0,1 ha każde, a $26 \%$ to gospodarstwa w przedziale obszarowym $0,1-0,5$ ha. W porównaniu z 1996 rokiem wzrosła liczba gospodarstw o powierzchni do 2 ha, a także w przedziałach $2-5$ ha oraz powyżej 5 ha. Gospodarstw większych niż 2-hektarowe było w 2002 roku 10 100, co stanowiło 2,93\% wszystkich gospodarstw $\mathrm{z}$ uprawami warzywniczymi (tab. 2). 
Tabela 2

Porównanie struktury ilościowej gospodarstw ogrodniczych w latach 1996 i 2002

\begin{tabular}{|c|c|c|c|}
\hline \multirow{3}{*}{ Lata } & \multicolumn{3}{|c|}{ Struktura gospodarstw ogrodniczych } \\
\hline & \multicolumn{3}{|c|}{ sadownicze } \\
\hline & $\begin{array}{c}\text { liczba gosp. ogółem } \\
\text { [w tys.] }\end{array}$ & $\begin{array}{c}\text { do } 2 \text { ha } \\
{[\%]}\end{array}$ & $\begin{array}{c}\text { pow. } 5 \text { ha } \\
{[\%]}\end{array}$ \\
\hline 1996 & 330,8 & 94 & $\begin{array}{c}1,9 \text { (1,9 tys. gospo- } \\
\text { darstw) }\end{array}$ \\
\hline 2002 & 272,6 & 90,5 & $\begin{array}{l}3,6 \text { (9,7 tys. gospo- } \\
\text { darstw) }\end{array}$ \\
\hline \multirow[b]{2}{*}{ Lata } & \multicolumn{3}{|c|}{ warzywnicze } \\
\hline & $\begin{array}{c}\text { liczba gosp. ogółem } \\
\text { [w tys.] }\end{array}$ & $\begin{array}{c}\text { do } 2 \text { ha } \\
{[\%]}\end{array}$ & $\begin{array}{c}\text { pow. } 2 \text { ha } \\
{[\%]}\end{array}$ \\
\hline 1996 & 1632 & 99,4 & $\begin{array}{c}0,6 \text { (10,1 tys. gospo- } \\
\text { darstw) }\end{array}$ \\
\hline 2002 & 616 & $97,1 \%$ & $\begin{array}{c}2,9 \text { (18,1 tys. gospo- } \\
\text { darstw) }\end{array}$ \\
\hline
\end{tabular}

Źródło: opracowania własne wg spisów rolnych 1996 i 2002.

Reasumując, należy stwierdzić, że mimo istotnego zmniejszenia się liczby gospodarstw, zwłaszcza warzywniczych, struktura ich wielkości pozostaje w dalszym ciągu niekorzystna, bo utrwala rozproszenie i zróżnicowanie technologiczne produkcji, powoduje nierównomierną podaż produktów zarówno w ciagu roku, jak i w poszczególnych latach.

$\mathrm{Z}$ analizy zasobów przechowalniczych gospodarstw sadowniczych wynika $\mathrm{z}$ kolei, że są one dostateczne w stosunku do ilości przechowywanych owoców (głównie jabłek) przy założeniu, że 60\% ich zbiorów przeznaczane jest dla przetwórstwa. Pojemność przechowalnicza wg spisu rolnego wynosiła w 2002 roku 800 tys. ton, co jest wielkością adekwatną do przechowywanych zbiorów, wynoszących w ostatnich latach ok. 800-1000 tys. ton. Niezadowalająca jest natomiast struktura rodzajów pomieszczeń przechowalniczych, gdyż chłodnie KA i UO stanowią tylko $13 \%$, a chłodnie zwykłe $31 \%$ ogólnej pojemności przechowalniczej, przez co nie można zagwarantować pożądanej jakości produktów ani równomierności ich dostaw na rynek. Proporcje te potwierdzają badania ankietowe przeprowadzone $\mathrm{w}$ grupie 100 gospodarstw $\mathrm{w}$ regionie Warki. Nie można jednak przyjąć a priori, że wszystkie gospodarstwa o powierzchni powyżej 5 ha osiagają corocznie dochody pozwalające na rekonstrukcję gospodarstw i koncentrację. 
Ocena potencjału produkcyjnego oraz jego zdolności do zaspokojenia rynku wewnętrznego i eksportu wypada korzystnie. Realnym natomiast zagrożeniem dla dotychczasowego poziomu konkurencyjności, a tym bardziej dla rozwoju tego sektora są organizacja i sposoby zarządzania nim. Należy stwierdzić, że brak jest istotnego postępu w działaniach organizacyjnych - przede wszystkim w sferze pozbiorczej, które mogłyby doprowadzić do koncentracji produkcji. Obecny stan organizacyjny obsługi handlowej w zakresie produktów ogrodniczych znajduje się w dalszym ciągu na poziomie znacznie niższym niż w okresie przed urynkowieniem gospodarki naszego kraju. Unicestwienie olbrzymiego majątku i struktur organizacyjnych spółdzielczości ogrodniczej oraz brak rozliczenia tego faktu i wskazania instytucji i osób odpowiedzialnych za ten stan rzeczy istotnie wpływa na niski stopień organizowania się nowych form współpracy. Również działania podjęte w ostatnich latach w tej sferze należy ocenić jako działania pozorne, mające $\mathrm{w}$ większości charakter jedynie propagandowy. Nie został zrealizowany program rządowy w zakresie rozwoju rynków hurtowych w dużych aglomeracjach miejskich. Środki publiczne zostały rozproszone na utworzenie bliżej nieokreślonych regionalnych i lokalnych rynków. Całkowicie pominięto rozwój podstawowego ogniwa w łańcuchu dystrybucyjnym, jakim miały być rynki producenckie. Ich zadaniem miała być integracja produkcji i producentów celem zaistnienia jako główny organizator dostaw podstawowych gatunków owoców i warzyw przez cały rok kalendarzowy, a przez to stanie się silnym i atrakcyjnym partnerem dla odbiorców krajowych i zagranicznych. Koncepcja koncentracji podaży przez rynki producenckie była ekonomicznie uzasadniona i konieczna wobec nieuchronności zmian spowodowanych wzrostem koncentracji detalicznej sieci sprzedaży na dużą skalę oraz rozwojem scentralizowanych form zakupów. W dalszej kolejności przewidywano nawiązanie kooperacji z producentami z innych krajów celem uzupełniania podaży w okresach jej naturalnego niedoboru w kraju. Ten model organizacyjny funkcjonowania producentów rozwijają obecnie związki producenckie poszczególnych krajów UE, tworząc zintegrowany system zarządzania produkcją i dystrybucja.

Zniszczenie spółdzielczości, a przez to struktur organizacyjnych, kooperacyjnych i integracyjnych oraz form współpracy między producentami, jak również błędna i nieracjonalna realizacja programu rządowego z początku lat 90 . spowodowały, że sektor ogrodniczy - a zwłaszcza producenci, którzy zostali zepchnięci do podrzędnej roli w łańcuchu dystrybucyjnym - znalazł się w próżni organizacyjnej. To przede wszystkim ten czynnik hamuje trwałą długookresową zdolność do konkurowania na rynkach krajowych i zagranicznych. Obecnie jest najwyższy czas, aby wnioski, zalecenia, rekomendacje, jakie pojawiają się od kilkunastu lat w różnych opracowaniach naukowych, dokumen- 
tach rządowych, konferencyjnych itp., gdzie dominują życzeniowe postulaty, należy zmienić na konkretne propozycje.

Jednym $z$ najważniejszych zadań jest zdynamizowanie działań w zakresie poziomej integracji producentów owoców $\mathrm{i}$ warzyw, która powinna doprowadzić do koncentracji przede wszystkim w sferze pozbiorczej tych produktów. Jednym z rozwiązań jest odsprzedaż (co nie zostało zrealizowane 10 lat temu) udziałów, które posiadaja na rynkach hurtowych agencje rządowe (ARR, ARiMR, ANR) grupom producenckim zorganizowanym i działającym w określonej formie prawnej, w pierwszej kolejności spółdzielniom.

Druga propozycja to przyjęcie określonej strategii rozwoju sektora, opartej na prozdrowotnym modelu żywienia jako bardzo istotnym w skali społecznej. Powinno to zintegrować pionowo cały łańcuch dystrybucyjny sektora ogrodniczego, który może mieć w tym zadaniu priorytetową rolę jako dostawca produktów szczególnie zalecanych we wspomnianym modelu żywienia.

Dodatkowym elementem sprzyjającym konkurencyjności polskiego ogrodnictwa może być upowszechnienie produkcji ekologicznej jako zapewniającej bezpieczeństwo spożywanych produktów, wyprodukowanych na możliwie niskim poziomie kontaminacji chemicznej i biologicznej.

\section{Literatura}

Analizy Rynkowe z lat 1995-2004: Rynek owoców i warzyw, Handel zagraniczny produktami rolno-spożywczymi, Popyt na żywność. Wydawnictwa IERiGŻ, Warszawa.

CIECHOMSKI W., 2002: Ocena możliwości poprawy konkurencyjności produktów ogrodniczych. Zeszyty Naukowe SGGW, Ekonomika i Organizacja Gopspodarki Żywnościowej, nr 46.

CIECHOMSKI W., MARZEC-WOŁCZYŃSKA T., NIEWIADOMSKI J., 2000: Rynek warzyw i owoców. Strategiczne opcje dla polskiego sektora agrobiznesu. Wydawnictwo SGGW.

NIEMCZYK J., 2000: Uwarunkowania polskiego handlu zagranicznego towarami rolno-żywnościowymi. Referat na konferencji FAPA, marzec 2000, Warszawa.

SOBIECKI R., 2003: Globalizacja i integracja gospodarki oraz ich skutki dla rolnictwa polskiego. http://www.arr.gov.pl

Uchwała Rady Ministrów Nr 126/2004. Ekonomiczne i społeczne uwarunkowania rozwoju polskiej gospodarki żywnościowej po wstapieniu Polski do UE. Program wieloletni 2005-2009. 


\section{Polish Horticulture in the Face of the International Competitiveness}

\section{Abstract}

The competitiveness of horticulture sector in Poland is decreasing due to the low productivity of factors to the production resulting from the little and dispersed scale of production as well as from the low level of vertical and horizontal integration of the majority of vegetable and orchard farms. Dispersed structure of the sector - reflected mainly in farms of small and medium area impacts on the incapability to compete with food processing plants and retail net on the equal principles. There is the lack of visible and effective forms of cooperation, coordination, information and communication between different entities functioning in the production sector, food processing industry and market. It all bring about, that long-term ability to gaining profits and maintaining current position, active and effective rivalry on domestic and international markets is to a high degree threatened. 